\title{
Never a Soul at Home: New Zealand Literary Nationalism and the 1930s
}

Reviewed by Paul Millar, Victoria University, Wellington

\author{
Never a Soul at Home: New Zealand Literary Nationalism and the \\ 1930s. \\ Stuart Murray \\ Victoria University Press, 1998.
}

Assuming New Zealand literature is still being studied in 2060, how will scholars view the 1990s? Might this decade be seen as a formative era against which writers of the future must somehow test and define themselves?

Let's imagine that in the second half of the $21^{\text {st }}$ century there is indeed an orthodox view of New Zealand writing in the 1990s; some neat, coherent story that academics annually narrate to successive generations of students. Then a new scholar comes along who, because of cultural and geographical distance, hasn't heard that tale; who reads outside the orthodox box, digs around, asks questions, even interviews survivors from the period.

This scholar tells a quite different story, arguing that the orthodox view doesn't really do the 1990 s justice. There were many more writers contributing to the literary scene; a number of vigorous presses were vying for a market share. The understanding of the decade in 2060 does not emerge purely from the decade itself, but is largely a construct of influential critics writing in the early part of the $21^{\text {st }}$ century-critics who were themselves stakeholders in the types of writing and critical discourse now accepted as orthodox. The critical ideas that are commonplace in this, the late $21^{\text {st }}$ century, concludes this scholar, are, in important respects, the victors' spoils left after a struggle for rhetorical control of the discourse.

I'll call a halt to this fancy before it gets the better of me (if it hasn't already). The point I am arriving at is that the imaginary achievements of my $21^{\text {st }}$ century scholar in interrogating an orthodox view of the 1990s, have a parallel in Stuart Murray's actual interrogation of our late $20^{\text {th }}$ century view of literary trends in the 1930s.

Given the range of events the 1930s calls to mind, it is hard for New Zealanders not to see the decade as one of the century's most significant. The great depression, the nation's approaching centenary, the impending war, the major move to the political left and resulting formation of the welfare state are

Kōtare 2, no. 2 (1999), pp. 78-81. 
just a few of the many occurrences that sent ripples into the future. Events of comparative magnitude were also affecting the literature of the time: the period saw the rise to prominence of Allen Curnow, the Caxton Press, Frank Sargeson, John Mulgan and Robin Hyde to name but a few leading literary influences. An emerging, confident, authentic voice proclaimed a new dawn of literary nationalism. Swept aside were the laments of deracinated colonisers, the prurient sentimentality of late-Victorian imitators, and the insipid gestures towards an indigenous English language literature of Georgian poetasters.

At least these days, that tends to be how the literary events of the 1930s are most frequently represented. It wasn't how Robin Hyde viewed things at the time. The writers and academics we now regard as the leaders in the development of New Zealand literary nationalism were to Hyde, in the terms of her 1938 essay 'The Singers of Loneliness', a type of literary 'gang'. It was the members of this gang that played a significant role in ensuring Hyde's extended stay on the margin's of the decade's writing. In 'The Singers of Loneliness', Hyde, with a little gang retaliation of her own, drolly characterises the groupR.A.K. Mason, A.R.D. Fairburn, Curnow, Denis Glover, lan Milner and Sargeson-as 'student writers'. While acknowledging their energy, she doesn't accord them the status they have since enjoyed. Nor does she credit the 1930s with some conscious and coherent development of literary nationalism. Instead she situates any moves towards a self-conscious national literature within a wider context of global politics and a global depression.

Murray works to some extent along Hyde's lines, taking an approach that is impressive for its detail and range of reference. For literary nationalists to properly construct myths of national identity, he argues, the complex influence of socialist politics must necessarily be disregarded. The focus must be tight, the view narrow. Murray's solution is to enrich the nationalist mix with generous re-inclusion of elements of the northern hemisphere literature and socialist politics that so clearly influenced New Zealand writing of the period. He does this in eight chapters, the titles of which fasten on a number of the decade's key figures: D'Arcy Cresswell, Mason, Ursula Bethell, Eileen Duggan, Fairburn, Sargeson, Hyde, Mulgan and Curnow. Still others, like Charles Brasch, M.H. Holcroft and Denis Glover weave their way in and out as it serves Murray's argument.

Not surprisingly, the books most powerful and pervasive figure is Curnow. Murray's discussion of the way Curnow's views and writing conditioned the approaches of fellow critics and poets, does much to explain why some authors made it into the nationalist canon and others fell outside it. Murray also counters the impression of the decade as one dominated by powerful male voices though 
his sections on Bethell, Duggan and Hyde. The greatest strength of the study, however, is that it makes almost no attempt to place a writer anywhere other than in, what the evidence suggests to be, their rightful place. There are no attempts to elevate the undeserving; all are judged on their achievements. Hyde, in particular, is found to have been poorly treated and so is positioned more centrally in a decade that she dominated in terms of both productivity and inventiveness.

My major reservation with Murray's study is, as some others have also commented, with his chapter on Mulgan. Murray argues that Mulgan 'has been the product of the most laborious nationalist myth-making....Yet the author and text read as being so central to local literary concerns was in fact easily the most peripheral.' He asserts that two of the leading proponents of New Zealand Literary nationalism-James Bertram and Paul Day-fastened on Mulgan because they found in him 'the perfect figure to compound the achievement perceived to originate in the Sargeson gaze.' The theory is predicated in part on an implication that Day and Bertram, through their privileged control over Mulgan's biography, were being in some respects duplicitous by placing his experience of the Queen Street riots in such a central position, and then firmly linking the events of the novel to the young Mulgan's life.

I can't fault Murray's analysis of the European cultural milieu in the late 1930s, and I'm grateful for his section detailing Mulgan's active participation in the intellectual and political activities of the period at the same time that he was writing Man Alone. Similarly, his discussion of Johnson's trek into the Kaimanawa Ranges, which he sees as a further example of a trend in the international writing of the 30s for images of 'frontiers and borders, and hence of countries and crossings' to serve as flexible symbols, is extremely valuable.

But I don't agree that such factors invalidate a nationalist response to the text. I remain unconvinced that Mulgan's global view of politics and his distance in time and space from the setting of the book would have blunted his understanding of the way the work was likely to be received. I find it equally difficult to accept that Bertram manufactured a view of Mulgan to accommodate a nationalist agenda. Bertram was himself very much an internationalist with a global, as well as a local, political sense. Few people were closer friends with Mulgan than Bertram, the two shared an experience of the riots and, if we are going to resurrect the beast from the bones of biography, then it is reasonable to suppose that Bertram, perhaps more than anyone, had a fair understanding of the effect of the depression on Mulgan.

At the most fundamental level, that of the text of Man Alone itself, claims for the importance of these depression experiences for Mulgan seem to be 
validated. As Trixie Te Arama Menzies pointed out, Mulgan's description of the Queen Street riots, the section that was for so long regarded as the realist heart of the novel, is perhaps the most poetic passage of prose in the book. Commenting on the climax of cathartic intensity followed by a fall, and carefully outlining 'the subtle but sustained use of water imagery' that structures the passage, Menzies identifies one of the few instances where the novel transcends mere reportage.

But even at the only real point at which I seriously disagree with Murray, I remain grateful for his insights and scholarship that should re-invigorate the debate surrounding this unusual man and his influential book.

Never a Soul at Home's strength derives from the expansiveness of Murray's view. Its value is in the onus it places on other scholars of New Zealand literature to revisit, and if necessary revise, their ideas about the formation of the literary nationalist canon. 